\title{
Future Flows Climate: an ensemble of 1-km climate change projections for hydrological application in Great Britain
}

\author{
C. Prudhomme ${ }^{1}$, S. Dadson ${ }^{2}$, D. Morris ${ }^{1}$, J. Williamson ${ }^{1}$, G. Goodsell ${ }^{1}$, S. Crooks ${ }^{1}$, L. Boelee ${ }^{1}$, \\ H. Davies ${ }^{1}$, G. Buys ${ }^{1,3}$, T. Lafon ${ }^{1}$, and G. Watts ${ }^{4}$ \\ ${ }^{1}$ Centre for Ecology and Hydrology, Maclean Building, Benson Lane, Crowmarsh Gifford, Wallingford, \\ OXON, OX10 8BB, UK \\ ${ }^{2}$ School of Geography and the Environment, University of Oxford, South Parks Road, Oxford, OX1 3QY, UK \\ ${ }^{3}$ British Antarctic Survey, High Cross, Madingley Road, Cambridge, CB3 0ET, UK \\ ${ }^{4}$ Evidence Directorate: Scientific and Evidence Services, Horizon House, Deanery Road, Bristol BS1 5AH, UK \\ Correspondence to: C. Prudhomme (chrp@ceh.ac.uk)
}

Received: 6 June 2012 - Published in Earth Syst. Sci. Data Discuss.: 27 June 2012

Revised: 31 October 2012 - Accepted: 13 November 2012 - Published: 16 November 2012

\begin{abstract}
The dataset Future Flows Climate was developed as part of the project "Future Flows and Groundwater Levels" to provide a consistent set of climate change projections for the whole of Great Britain at both space and time resolutions appropriate for hydrological applications, and to enable climate change uncertainty and climate variability to be accounted for in the assessment of their possible impacts on the environment.

Future Flows Climate is derived from the Hadley Centre's ensemble projection HadRM3-PPE that is part of the basis of UKCP09 and includes projections in available precipitation (water available to hydrological processes after snow and ice storages have been accounted for) and potential evapotranspiration. It corresponds to an 11-member ensemble of transient projections from January 1950 to December 2098, each a single realisation from a different variant of HadRM3. Data are provided on a 1-km grid over the HadRM3 land areas at a daily (available precipitation) and monthly (PE) time step as netCDF files.
\end{abstract}

Because systematic biases in temperature and precipitation were found between HadRM3-PPE and gridded temperature and precipitation observations for the 1962-1991 period, a monthly bias correction procedure was undertaken, based on a linear correction for temperature and a quantile-mapping correction (using the gamma distribution) for precipitation followed by a spatial downscaling. Available precipitation was derived from the bias-corrected precipitation and temperature time series using a simple elevation-dependant snow-melt model. Potential evapotranspiration time series were calculated for each month using the FAO-56 Penman-Monteith equations and bias-corrected temperature, cloud cover, relative humidity and wind speed from HadRM3-PPE along with latitude of the grid and the day of the year.

Future Flows Climate is freely available for non-commercial use under certain licensing conditions. It is the dataset used to generate Future Flows Hydrology, an ensemble of transient projections of daily river flow and monthly groundwater time series for representative river basins and boreholes in Great Britain.

doi:10.5285/bad1514f-119e-44a4-8e1e-442735bb9797. 


\section{Background}

Climate change may increase temperatures and change rainfall across England, Wales and Scotland (Murphy et al., 2009). In turn, this may modify patterns of river flow and groundwater recharge, affecting the availability of water and changing the aquatic environment. There have been many studies of the impact of climate change on river flows in different parts of the UK (e.g. Charlton and Arnell, 2011; Diaz-Nieto and Wilby, 2005; Holman, 2006; Kay et al., 2009; Ledbetter et al., 2011; Limbrick et al., 2000; Lopez et al., 2009; Nawaz and Adeloye, 2006; Prudhomme and Davies, 2009; Prudhomme et al., 2010; Wilby and Harris, 2006; Kay and Jones, 2010), but coverage is uneven and methods vary. This means it is very difficult to compare different locations, complicating the identification of appropriate adaptation responses.

The project "Future Flows and Groundwater Levels" was established to provide datasets and products facilitating the assessment of climate change impact on a range of waterrelated issues across Great Britain within a nationally consistent framework. Future Flows Climate is a consistent set of climate change projections for the whole of Great Britain at both space and time resolutions appropriate for hydrological applications, and to enable climate change uncertainty and climate variability to be accounted for in the assessment of their possible impacts on the environment.

At the end of the project, the transient daily time series and the datasets necessary for their calculations were made accessible to the research community so that further impact analyses can be made on a range of specific areas such as fishery, freshwater ecology, water availability etc. The length (around $150 \mathrm{yr}$ ) and geographical spread (over Great Britain) of the time series will enable powerful spatio-temporal analysis of the impact of climate change on UK rivers, possible for the first time at such a scale in the UK thanks to a strict methodological framework which ensures consistency, and hence comparability, of all generated data.

This paper gives an overview of the climate projections at the origin of Future Flows Climate (Sect. 2), then describes how temperature, precipitation and potential evapotranspiration time series were derived. It concludes by considering some of the limitations of Future Flows Climate and how to access the data.

\section{Data: the ensemble of climate projections HadRM3-PPE}

\subsection{Description}

Future Flows Climate is based on HadRM3-PPE-UK, a set of transient climate projections for the UK that were used as part of the derivation of the UKCP09 scenarios (Murphy et al., 2007). HadRM3-PPE-UK is an experiment designed to simulate the regional climate for the UK for the period
Table 1. HadRM3-PPE run ID, climate sensitivity and model variant name. From http://badc.nerc.ac.uk.

\begin{tabular}{lcc}
\hline run ID & $\begin{array}{c}\text { Climate sensitivity of corresponding } \\
\text { HadSM3 variant }(\mathrm{K})\end{array}$ & name \\
\hline afgcx & 3.53485 & HadRM3Q0 \\
afixa & 2.58475 & HadRM3Q3 \\
afixc & 2.81543 & HadRM3Q4 \\
afixh & 3.43839 & HadRM3Q6 \\
afixi & 4.39594 & HadRM3Q9 \\
afixj & 3.89523 & HadRM3Q8 \\
afixk & 4.44284 & HadRM3Qk \\
afixl & 4.88248 & HadRM3Q14 \\
afixm & 4.54486 & HadRM3Q11 \\
afixo & 4.79648 & HadRM3Q13 \\
afixq & 7.11014 & HadRM3Q16 \\
\hline
\end{tabular}

1950-2100 for historical and SRES A1B emissions scenarios; while it aims to represent parameter uncertainty through a parameter variant experiment, the ensemble undersamples the GCM uncertainty and excludes emissions scenario uncertainty. It contains the output of the Met Office Hadley Centre's Regional Climate Model HadRM3 used to dynamically downscale the global climate model HadGM3 results. It consists of an 11-member ensemble, each driven by the same historical and SRES A1B emissions, with one unperturbed member and 10 members with different perturbations to the atmospheric parametrisations (Murphy et al., 2009). The climate sensitivities associated with each ensemble member along with their run ID and model name are given in Table 1. Detailed information on the model ensemble can be found at http://badc.nerc.ac.uk/data/hadrm3-ppe-uk/.

The HadRM3-PPE time series are provided at a $25-\mathrm{km}$ grid spatial resolution and daily time temporal resolution. However, brief analyses of precipitation and temperature time series for the historical (pre-2000) period showed systematic differences from observations. This is a common feature in regional climate model outputs, mainly because their coarse spatial resolution does not allow for small-scale (temporal and spatial) atmospheric processes to be adequately reproduced. Because this can have implications when used to model river flow and groundwater levels, the HadRM3-PPE daily outputs were modified using a statistical technique so that their statistical properties match those of the observations, for the same periods. In addition, a spatial downscaling was applied, to incorporate the spatial heterogeneity observed in precipitation within each $25-\mathrm{km}$ grid square. Table 2 lists the variables used to derive Future Flows Climate time series of available precipitation and potential evapotranspiration. 
Table 2. HadRM3-PPE variables used to derive Future Flows Climate.

\begin{tabular}{lllll}
\hline NedCDF Variable ID & Stash code & Long name & CF standard name & Unit \\
\hline tas & M1s3i236 & Mean temperature at $1.5 \mathrm{~m}$ & Air_temperature & ${ }^{\circ} \mathrm{C}$ \\
pr & M1s5i216 & Total precipitation rate & Precipitation_flux & $\mathrm{kg} \mathrm{m}^{-2} \mathrm{~s}^{-1}$ \\
hurs_pc & M1s3i245 & Mean relative humidity at $1.5 \mathrm{~m}$ & $\%$ \\
Total_cloud_lw_rad & M1s2i024 & Total cloud amount in longwave radiation & & 1 \\
wss & M1s3i249 & Mean 10 m wind speed & Wind_speed & $\mathrm{m} \mathrm{s}^{-1}$ \\
\hline
\end{tabular}

\subsection{Temperature}

HadRM3-PPE daily temperature time series were spatially downscaled and bias-corrected based on the 5-km daily temperature time series UKCP09 gridded observation datasets (Perry et al., 2009). A linear additive transfer function (Leander and Buishand, 2007) was applied to the HadRM3-PPE temperature time series at the $5-\mathrm{km}$ resolution of the observation for each month. The parameters of the transfer function were estimated so that, for each $5-\mathrm{km}$ grid cell and over the period 1962-2000, mean monthly bias-corrected temperature matched the mean monthly observed temperature over the same area. Each transfer function was calculated independently hence resulting in 11 sets of 12 transfer functions for each 5-km cell of UKCP09 temperature grid. The sets were then applied to each day of the 1950-2098 HadRM3PPE temperature ensemble members.

Bias-corrected temperature is an intermediate product and not part of Future Flows Climate.

\subsubsection{Future Flows Climate: available precipitation}

With temperature rising, the partition of precipitation between rainfall and snowfall in snow-influenced regions (such as for example Scotland and some parts of northern England and Wales) is likely to differ from that observed historically. However, the role of precipitation in the hydrological processes and runoff generation differs greatly depending on whether it falls as rain or snow, because water contained in snow (and ice or snow-pack) is locked for a certain period and does not run-off immediately. With a warming of the climate, snow-driven delay is likely to play a smaller role, potentially modifying river flow seasonal pattern.

\subsection{Spatial downscaling and bias correction}

Spatial downscaling and bias correction were first performed on HadRM3-PPE precipitation time series. Similarly to Piani et al. (2010) precipitation and temperature bias-corrections were done independently. While this might introduce some physical discrepancies between both variables as it might modify their relationships, the introduced uncertainty is considered small compared to the range of other uncertainty sources.
The procedure uses a $25-\mathrm{km}$ average observed daily precipitation matching the resolution of HadRM3-PPE aggregated from the $1-\mathrm{km}$ daily observed precipitation time series (Keller et al., 2006) to establish a transfer function for each month and each $25-\mathrm{km}$ grid of the averaged observational data. The transfer function follows the parametric quantilemapping method described by Piani et al. (2010) based on the gamma distribution; it aims to minimise the difference between those observed and simulated daily pattern at that grid. When applied to the HadRM3-PPE daily time series (with total precipitation converted into $\mathrm{mm}$ for each day), this transfer function generates a new $25-\mathrm{km}$ bias-corrected gridded daily time series where most of the statistical properties (and in particular the first two statistical moments of daily rainfall) are similar to the observed for the same historical period 1962-1991. Applying the bias correction to 25-km grid scale ensures that spatial dependency of rainfall time series (important for hydrological modelling) within each grid square is maintained. This is not guaranteed from one grid to another, but the evaluation of the resulting time series at catchment scale suggests the method to be appropriate (not shown). The time series is then further downscaled at $1-\mathrm{km}$ based on the observed annual precipitation variability within each grid, so that the sub-grid orographic effect can be included within the generated 1-km time series. Fuller description of the method and its validation can be found in Newton et al. (2012).

\subsection{Accounting for snow melt processes}

Snow-melt processes are accounted for by using a simple elevation-dependent snow-melt model (Bell and Moore, $1999)$ to estimate when water is available for runoff. Each 1$\mathrm{km}$ grid is subdivided into elevation bands of $50-\mathrm{m}$ vertical extent using elevation data from the CEH Integrated Hydrological Digital Terrain Model (Morris and Flavin, 1990). For temperature calculation each band is treated as being at the elevation of its mid-range. A lapse rate (linear reduction of temperature with elevation) is used for converting the values from the 5-km temperature bias-corrected gridded time series to values applicable in the $1-\mathrm{km}$ grids. Table 3 lists the parameters and the values used. Note that no allowance has been made for the effects of lakes.

Each of the 11 1-km bias-corrected and downscaled precipitation daily time series is transformed in 1-km "available 
Table 3. Snowmelt model parameters.

\begin{tabular}{lll}
\hline Parameter & Definition & Value used \\
\hline tlapse & $\begin{array}{l}\text { Temperature lapse rate }- \text { reduction in air temperature } \\
\text { with increasing elevation. }\end{array}$ & $0.59{ }^{\circ} \mathrm{C} / 100 \mathrm{~m}$ \\
\hline tsnow & Critical temperature, below which precipitation is snow. & $1{ }^{\circ} \mathrm{C}$ \\
\hline tmelt & Threshold temperature for snowmelt. & $0{ }^{\circ} \mathrm{C}$ \\
\hline mfac & $\begin{array}{l}\text { Melt factor (mm per day per }{ }^{\circ} \mathrm{C} \text { by which the tempera- } \\
\text { ture exceeds tmelt) }\end{array}$ & $6.0 \mathrm{~mm}^{\circ} \mathrm{C}^{-1} \mathrm{day}^{-1}$ \\
\hline tdrel & Threshold temperature for drainage release. & $0{ }^{\circ} \mathrm{C}$ \\
\hline $\mathrm{k} 1, \mathrm{k} 2$ & Storage time constants of two-outlet liquid water store. & $0.5 \mathrm{day}^{-1}, 0.9 \mathrm{day}^{-1}$ \\
\hline Sc & Critical water retention capacity. & 0.2 \\
\hline rgfac & Under-catch factor for gauged rainfall falling as snow. & 1.1 \\
\hline
\end{tabular}

precipitation" (APr, in $\mathrm{mm}$ ) 148-yr time series using this method, and using the bias-corrected temperature time series.

\subsection{Treatment of non-calendar year}

The HadRM3-PPE generates precipitation and temperature time series according to an artificial year of 360 days grouped into twelve 30-day months. However, the requirement for the water available from precipitation time series was for Gregorian years (365/6 days) for use in generating river flow times series that can readily be compared with observations. This was achieved by inserting five zero-rainfall days (six in a leap year) into each year of HadRM3-PPE data.

For each individual year, insertion dates were selected for the additional days according to the following criteria:

- The same set of dates must be used at all grid points in GB in order to avoid any spatial discontinuities within rainfall events.

- The dates must be within \pm 20 days of days 36,108 , 180, 252 and $324(30,90,150,210,270$ and 330 for leap years).

- Within each of these ranges, the preferred date is the one at which insertion of a zero-rainfall day will interrupt a two-day rainfall sequence (defined as two consecutive days with more than $5 \mathrm{~mm}$ of rainfall) at the smallest number of grid points in GB.

The temperature on the inserted zero-rainfall days was set to the average of that on the preceding and following day.

\subsection{File format}

Available precipitation time series from Future Flows Climate are saved in different netCDF files to increase the speed of downloading, copying, reading and manipulations. APr datasets (corresponding to the total daily available precipitation expressed in $\mathrm{mm}$ ) from each 11-ensemble member are saved separately and for 30-yr periods. File names contain the name of the ensemble member consistently with the Hadley Centre's notations (run ID in Table 1) and the time period. A total of $11 \times 5=55$ files describe the entire APr dataset, of $18.5 \mathrm{~Gb}$ each. The entire time series period ranges from 1950 to 2098. More information on method and its validation is described in Morris (2012).

\section{Potential evapotranspiration}

Evapotranspiration is an important element of the hydrological processes as it represents the main loss of water from precipitation to runoff. Evaporative and transpiration losses are complex processes depending on available water and energy (hence including feedbacks) and on plant demands. Potential evapotranspiration is the simplified concept of losses that would occur if water were un-limited and did not depend on antecedent conditions. Potential evapotranspiration has been found to be a useful conceptualisation for detailed hydrological and hydrogeological modelling.

Potential evapotranspiration at 5-km resolution was generated using HadRM3-PPE climate time series, based on the FAO-56 Penman-Monteith method (Allen et al., 1998). The 5-km downscaled and bias-corrected daily temperature time series were used as they are a more realistic representation of temperature than HadRM3-PPE tas. Vapour pressure was calculated from mean temperature and relative humidity; net radiation was derived from latitude, day of the year, cloud cover (with 1-Total_cloud_lw_rad $=f$ cloudiness factor) and vapour pressure (Shuttleworth, 1993). For each 5-km grid cell of the bias-corrected temperature dataset, the associated HadRM3-PPE grid cell was identified and the relevant climate time series extracted. PE was then estimated for the 
15th of the month using mean monthly averages from all relevant climate variables associated with the same climate projection ensemble member to produce a monthly time PE time series for 1950 to 2098 for that member.

\section{File format}

Because of the volume of data describing Future Flows Climate PE, the time series were saved in different netCDF files to increase the speed of downloading, copying, reading and manipulations. For consistency with Future Flows Climate APr, Future Flows Climate PE is saved at $1-\mathrm{km}$ grid. PE datasets (corresponding to the mean monthly PE expressed in $\mathrm{mm} \mathrm{day}^{-1}$ ) from each 11-ensemble member are saved separately as 30 -yr period. File names contain the name of the ensemble member consistently with the Hadley Centre's notations (run ID) and the time period. A total of $11 \times 5=55$ files describe the entire PE dataset, of $1.25 \mathrm{~Gb}$ each. The entire time series period ranges from 1950 to 2098.

\section{Limitations of Future Flows Climate}

Future Flows Climate is the ensemble gridded climate data of the Future Flow and Groundwater Level project; its acronym is FF-HadRM3-PPE. It covers England, Wales and Scotland. The dataset has been developed within the project using a consistent approach nationally, hence enabling comparison of results across a range of scales and geographical regions. Future Flows Climate is derived from the eleven members of HadRM3-PPE ensemble simulations of the climate, based on the SRES emission scenarios A1B. The downscaling and bias correction procedures applied to the HadRM3-PPE were considered necessary to provide a product that is appropriate for hydrological and groundwater level simulations. However, the techniques used are not physically based, and Future Flows Climate will still contain some discrepancies compared to "real climate".

Future Flows Climate time series range from 1950 to 2098 and are provided at a $1-\mathrm{km}$ grid resolution, which is a resolution suitable for most hydrological applications. They consist of 11 different (equally likely) plausible realisations of the climate over this period under the A1B emission scenario. This means that they are designed to capture the natural temporal and spatial variability expected in the climate as well as possible, but they do not reproduce historical weather sequences. In other words, none of the Future Flows Climate time series of precipitation or temperature are expected to provide, for the period 1975-1976, the same weather sequence as observed in 1975-1976. However, within the longer period of 1951-2000, it is expected the main day-to-day patterns characteristic of the climate of Great Britain resemble those observed at any point. This is showed by the error associated with FF-HadRM3-PPE as input of rainfall-runoff models being within acceptable modelling errors (Prudhomme et al., 2012).

\section{Access}

Future Flows Climate dataset is associated with a digital object identifier doi:10.5285/bad1514f-119e-44a4-8e1e442735bb9797. This must be referenced fully for every use of the Future Flows Climate data as follows:

Prudhomme C., Dadson S., Morris D., Williamson J., Goodsell G., Crooks, S., Boelee L., Davies H., Buys G., and Lafon T.: "Future Flows Climate", doi:10.5285/bad1514f-119e-44a4-8e1e442735bb9797, 2012.

All Future Flows Climate files (55 files for APr, 55 files for PE) are available through the CEH Environmental Informatics Data Centre Gateway under special licensing conditions (https://gateway.ceh.ac.uk/ or doi:10.5285/bad1514f119e-44a4-8e1e-442735bb9797).

\section{Conditions of use}

Future Flows Climate is available under licensing condition agreement. For non-commercial use, the product is available free of charge. For commercial use, the data might be made available conditioned to a fee to be agreed upon with CEH licensing team, owner of the IPR of the datasets and products.

Acknowledgements. Future Flows Climate has been generated under the partnership project "Future Flows and Groundwater Levels, SC090016" jointly funded by the Environment Agency for England and Wales, the UK Department for Environment, Food and Rural Affairs, the UK Water Industry Research, the Natural Environment Research Centre (CEH and BGS) and Wallingford HydroSolutions. They are all gratefully acknowledged.

Edited by: N. Verhoest

\section{References}

Allen, R. G., Pereira, L. S., Raes, D., and Smith, M.: FAO irrigation and drainage paper 56 - Crop evapotranspiration - Guidelines for computing crop water requirements, Food and Agriculture Organisation of the United Nations, Rome, 300 pp., 1998.

Bell, V. A. and Moore, R. J.: An elevation-dependent snowmelt model for upland Britain, Hydrol. Process., 13, 1887-1903, 1999.

Charlton, M. B. and Arnell, N. W.: Adapting to climate change impacts on water resources in England - An assessment of draft Water Resources Management Plans, Global Environ. Change, 21, 238-248, doi:10.1016/j.gloenvcha.2010.07.012, 2011.

Diaz-Nieto, J. and Wilby, R. L.: A comparison of statistical downscaling and climate change factor methods: Impacts on low flows in the River Thames, United Kingdom, Clim. Change, 69, 245268, 2005.

Holman, I.: Climate change impacts on groundwater recharge - uncertainty, shortcomings, and the way forward?, Hydrogeol. J., 14, 637-647, 2006. 
Kay, A. L. and Jones, D. A.: Transient changes in flood frequency and timing in Britain under potential projections of climate change, Int. J. Climatol., 32, 489-502, doi:10.1002/joc.2288, 10.1002/joc.2288, 2010.

Kay, A. L., Davies, H. N., Bell, V. A., and Jones, R. G.: Comparison of uncertainty sources for climate change impacts: flood frequency in England, Clim. Change, 92, 41-63, doi:10.1007/s10584-008-9471-4, 2009.

Keller, V., Young, A. R., Morris, D., and Davies, H.: Continuous Estimation of River Flows (CERF) Technical Report: Estimation of Precipitation Inputs, Centre for Ecology and Hydrology, Wallingford, 2006.

Leander, R. and Buishand, T. A.: Resampling of regional climate model output for the simulation of extreme river flows, J. Hydrol., 332, 487-496, 2007.

Ledbetter, R., Prudhomme, C., and Arnell, N.: A method for incorporating climate variability in climate change impact assessments: Sensitivity of river flows in the Eden catchment to precipitation scenarios, Clim. Change, 113, 803-823, doi:10.1007/s10584-011-0386-0, 2011.

Limbrick, K. J., Whitehead, P. G., Butterfield, D., and Reynard, N.: Assessing the potential impacts of various climate change scenarios on the hydrological regime of the River Kennet at Theale, Berkshire, south-central England, UK: an application and evaluation of the new semi-distributed model, INCA, Sci. Total Environ., 251-252, 539-555, 2000.

Lopez, A., Fung, F., New, M., Watts, G., Weston, A., and Wilby, R. L.: From climate model ensembles to climate change impacts and adaptation: A case study of water resource management in the southwest of England, Water Resour. Res., 45, W08419, doi:10.1029/2008wr007499, 2009.

Morris, D.: Derivation of water available from precipitation, $\mathrm{CEH}$, Wallingford, 17 pp., 2012.

Morris, D. G. and Flavin, R. W.: A digital terrain model for hydrology, Proceedings 4th international symposium on spatial data handling, Zurich (CH), 250-262, 1990.

Murphy, J. M., Booth, B. B. B., Collins, M., Harris, G. R., Sexton, D. M. H., and Webb, M. J.: A methodology for probabilistic predictions of regional climate change from perturbed physics ensembles, Philos. T. R. Soc. A, 365, 1993-2028, doi:10.1098/rsta.2007.2077, 2007.
Murphy, J. M., Sexton, D. M. H., Jenkins, G. J., Booth, B. B. B., Brown, C. C., Clark, R. T., Collins, M., Harris, G. R., Kendon, E. J., Betts, R. A., Brown, S. J., Humphrey, K. A., McCarthy, M. P., McDonald, R. E., Stephens, A., Wallace, C., Warren, R., Wilby, R., and Wood, R. A.: UK Climate Projections Science Report: Climate Change Projections, Met Office Hadley Centre, Exeter, UK, 190 pp., 2009.

Nawaz, N. R. and Adeloye, A. J.: Monte Carlo Assessment of Sampling Uncertainty of Climate Change Impacts on Water Resources Yield in Yorkshire, England, Clim. Change, 78, 257-292, 2006.

Newton, G., Dadson, S. J., Lafon, T., and Prudhomme, C.: Scoping study for precipitation downscaling and bias-correction Science report/Project Note SC090016/PN3, CEH Wallingford, Wallingford, 41 pp., 2012.

Perry, M., Hollis, D., and Elms, M.: The generation of daily gridded datasets of temperature and rainfall for the UK, National Climate Information Centre, Met Office, Exeter, 7 pp., 2009.

Piani, C., Haerter, J. O., and Coppola, E.: Statistical bias correction for daily precipitation in regional climate models over Europe, Theor. Appl. Climatol., 99, 187-192, 2010.

Prudhomme, C. and Davies, H.: Assessing uncertainties in climate change impact analyses on the river flow regimes in the UK. Part 2: future climate, Clim. Change, 93, 197-222, 2009.

Prudhomme, C., Wilby, L. R., Crooks, S. M., Kay, A. L., and Reynard, N. S.: Scenario-neutral approach to climate change impact studies: application to flood risk, J. Hydrol., 390, 198-209, 2010.

Prudhomme, C., Crooks, S., Jackson C., Kelvin, J., and Young, A.: Final Technical Report. Science Report/Project Note SC090016/PN9, CEH, BGS, WHS, EA, UKWIR, 116 pp., 2012.

Shuttleworth, W. J.: Evaporation, in: Handbook of hydrology, edited by: Maidment, D. R., McGraw-Hill, Inc, 4.1-4.53, 1993.

Wilby, R. L. and Harris, I.: A framework for assessing uncertainties in climate change impacts: Low-flow scenarios for the River Thames, UK, Water Resour. Res., 42, W02419, doi:10.1029/2005wr004065, 2006. 